\title{
The Right to Water Before Investment Tribunals
}

\author{
Ursula Kriebaum \\ Universitat Wien \\ ursula.kriebaum@univie.ac.at
}

\begin{abstract}
Access to safe drinking water and potential water degradation have played a role in many water-related investment arbitrations. This paper looks at two different types of investment cases that have emerged with an impact on water: First, it analyses cases that have arisen from privatizations in the water sector. They mainly concern problems connected with physical access to water and affordability. Second, it discusses cases concerning investments in other industries that have the potential to degrade water quality or to have a negative impact on the maritime environment. Using these typical constellations it focuses on the methodology tribunals adopt to deal with potential tensions between the right to water and investor rights.
\end{abstract}

\section{Keywords}

international investment law - international investment arbitration - human rights right to water

Access to safe drinking water and potential water degradation has played a role in many water-related investment arbitrations. Two different types of investment cases with an impact on water have emerged. One form of investment dispute that has arisen from privatizations in the water sector mainly concerns

* The present article was presented during the Workshop of the Interest Group on International Economic Law of the European Society of International Law devoted to 'Global Public Goods, Global Commons, Fundamental Values: The Responses of International Economic Law', held in Naples on 6 September 2017.

(C) KRIEBAUM, 2018 | DOI 10.1163/23527072-00101005

This is an open access article distributed under the terms of the prevailing CC-BY License at the time of publication. 
problems regarding physical access to water and affordability. Another set of cases concerns investments in other industries that have the potential to degrade water quality or have a negative impact on the maritime environment.

In water-related cases, investment tribunals have had to deal with disputes arising out of:

- disagreements between investors and authorities concerning tariff regimes and their effect on the affordability of water, especially, but not only, in times of economic crises;

- failures to establish an agreed number of water connections due to noncompliance of an investor with an investment contract;

- threats of pollution to ground and drinking water resources and risks of harm to the marine environment.

With regard to the question of who raised the human rights/water pollution issue, the picture is mixed. We find cases where only the government raised the issue, such as in Azurix or SAUR, instances where only the amicus curiae invoked human rights and cases where both the government and the amici relied on human rights arguments. In some cases, such as Biwater Gauff or Methanex, it is only the amici that based themselves on human rights arguments. ${ }^{1}$ The responding governments invoked their duty to assure access to drinking water without explicitly referring to human rights specifically or obligations under international law in general.

All cases dealing with access to water and discussed here share the feature that they originated from privatization processes, in which the investor or its

1 On amicus curiae see, for instance, Stanimir A. Alexandrov and Marrin Carlson, "The Opportunity to be Heard', in Miguel Fernández-Ballesteros and David Arias (eds.), Liber Amicorum: Bernardo Cremades (Alphen aan den Rijn: Kluwer, 2010), pp. 49-64; Nigel Blackaby and Caroline Richard, 'Amicus Curiae: A Panacea for Legitimacy in Investment Arbitration', in Michael Waibel et al. (eds.), The Backlash against Investment Arbitration, Perceptions and Reality (Alphen aan den Rijn: Kluwer, 2010) pp. 253-274; Eugenia Levine, 'Amicus Curiae in International Investment Arbitration', Berkeley Journal of International Law, 29: 200-224 (2011). 
subsidiaries obtained a concession for water and sewage supply. All of them concern issues relating to fees, arising where governments interfere ex post with investor rights in an effort to assure that water is affordable for consumers.

The concessions granted in these cases predate General Comment 15 of the UN Committee on Economic, Social and Cultural Rights on the Right to Water of 2002. ${ }^{2}$ General Comment 15 contains important principles with regard to privatization that can also be applied to foreign investments. It contextualizes issues relating to affordability, physical access and water quality with one another and clarifies that the human right to water entitles everyone to sufficient, safe, acceptable, physically accessible and affordable water for personal and domestic use. This right constitutes both a component of the right to an adequate living standard, including adequate housing and food protected by Article 11(1) of the UN Covenant on Economic, Social and Cultural Rights, as well as the right to the highest attainable standard of health guaranteed by Article 12 of the same Covenant. ${ }^{3}$

As clarified by the Committee, the normative content of the right to water contains both freedoms and entitlements. ${ }^{4}$ These freedoms comprise access to existing water supplies, which is necessary to initially realize the right to water, and the right to be free from interference, arbitrary disconnections or contamination of water supplies, once access has been achieved. Entitlements include the right to a system of water supply and management that provides equality of opportunity to enjoy the right to water. ${ }^{5}$ Here, the focus is clearly placed on personal and domestic use. ${ }^{6}$

2 UN Committee on Economic, Social and Cultural Rights (CESCR), General Comment No. 15: The Right to Water (Arts. 11 and 12 of the Covenant), E/C.12/2002/11, 20 January 2003 (hereinafter CESCR General Comment No. 15).

3 CESCR General Comment No. 15, supra note 2, para. 2; see also UN Committee on Economic, Social and Cultural Rights (CESCR), General Comment No. 6: The Economic, Social and Cultural Rights of Older Persons, E/1996/22, 8 December 1995, para. 32. The Human Rights Council (HRC) confirmed this deduction in its resolution, HRC, 'Human Rights and Access to Safe Drinking Water and Sanitation', A/HRC/RES/15/9, 6 October 2010, para. 3 .

4 CESCR General Comment No. 15, supra note 2, para. 10.

5 Ibid., para. 10.

6 Ibid., para. 15 reads in this regard: 'The human right to water entitles everyone to sufficient, safe, acceptable, physically accessible and affordable water for personal and domestic use'. These uses comprise water for drinking, washing clothes, food preparation and personal and household hygiene (para. 12(a)). See also Jorge E. Viñuales, 'Access to Water in Foreign Investment Disputes', Georgetown International Environmental Law Review, 21/4: 733-759 (2009), p. 739 . 
For the purposes of investment law, the paragraphs of the General Comment dealing with privatization issues that mention positive obligations incumbent upon States are especially important. These include:

- preventing third parties from interfering with the enjoyment of the right to water ${ }^{7}$ or compromising equal, affordable, and physical access to sufficient, safe and acceptable water in any way; 8

- preventing companies based in their territory from violating the right to water in other countries (host countries of investments); ${ }^{9}$

- preventing arbitrary or unjustified disconnection or exclusion from water services or facilities. ${ }^{10}$

In this context, it is also worth considering that under no circumstances may an individual be deprived of the minimum essential level of water.1

Given that the relevant concessions predate the General Comment, these clarifications on the right to water provided by the UN Committee on Economic Social and Cultural Rights were neither available to investors nor to host States, at the time the concessions were issued. Similarly, the European Court of Human Rights has not yet dealt with water affordability and could therefore not have provided any guidance on the issue at the time. As a result, the exact requirements of the human right to water in terms of affordability were not clear when the foreign investors in the cases examined here obtained their concessions. ${ }^{12}$

An early case that dealt with the affordability of water was Aguas del Tunari, $S A$ v. Bolivia. ${ }^{13}$ It concerned a 40-year water-supply contract concluded in 1999 between a consortium and the Bolivian Water and Electricity Superintendencies. ${ }^{14}$ Subsequent to the concession being granted, significant opposition surfaced in various parts of the country. Objections were particularly fierce in Cochabamba, Bolivia's third largest city, where the water and sewage service

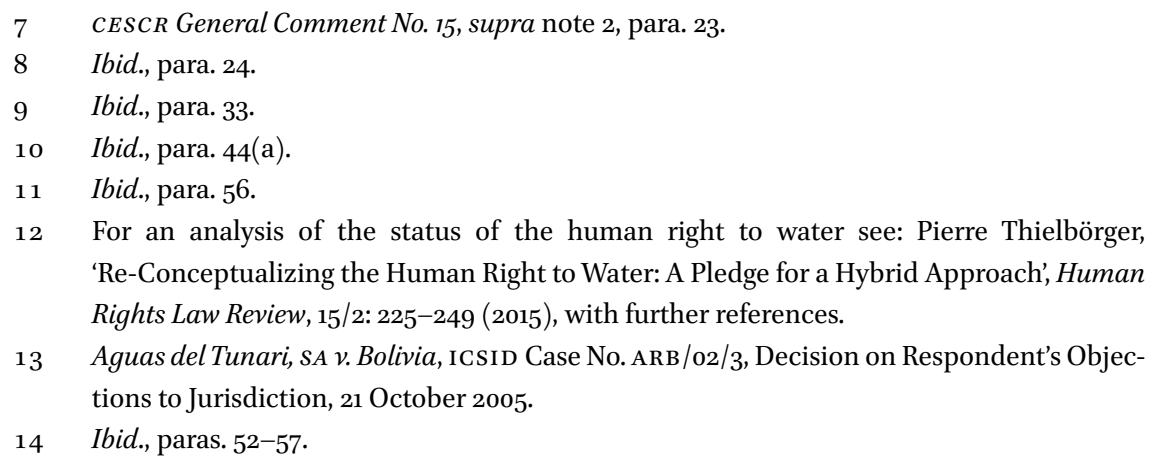


was being privatized. ${ }^{15}$ Although operations of the new supplier had only begun in January 2000, major violent protests led to the termination of the concession by April of the same year. ${ }^{16}$ These demonstrations had primarily been driven by important increases of water fees and fears that private or cooperative water wells could no longer be utilized as before the privatization. ${ }^{17}$ After initial negotiations with the government failed, Aguas del Tunari filed a request for arbitration with the International Centre for Settlement of Investment Disputes (ICSID) in November 2001, before finally reaching a settlement in January 2006. They declared that the concession had only been terminated as a result of civil unrest and a state of emergency in Cochabamba (as opposed to any shortcomings on the part of the investor). The parties agreed that neither the Government of Bolivia nor Aguas del Tunari would receive compensation for termination of the concession and they agreed on the withdrawal of the ICSID claim. ${ }^{18}$ Given that the case never reached the merits phase, the Tribunal did not have the opportunity to elaborate upon the relationship between the human right to water and investment protection standards. Yet, from a political perspective, the case illustrates that providing for participation of the local population during the privatization process can be useful in order to avoid civil unrest once a concession has been awarded.

In Azurix v. Argentina, ${ }^{19}$ the Tribunal was called upon to examine a dispute arising out of the Argentinian water privatization process. $\mathrm{ABA}$, an indirect subsidiary of Azurix, had obtained a 30-year concession for the distribution of potable water and the treatment of sewage in the Province of Buenos Aires. After the latter had failed to fulfill its obligations under the concession agreement in terms of conducting infrastructure repair works, an algae bloom in a reservoir resulted in water contamination. ${ }^{20}$ The government declared the water unfit for consumption and blamed the foreign investor for the poor water

\footnotetext{
15 Ibid., para. 73 .

16 Ibid., para. 73 .

17 Maria McFarland Sánchez-Moreno and Tracy Higgins, 'No Recourse: Transnational Corporations and the Protection of Economic, Social, and Cultural Rights in Bolivia', Fordham International Law Journal, 27/5: 1163-1805 (2004), p. 1763.

18 See information by Bechtel: 'Bechtel Perspective on the Aguas del Tunari water concession in Cochabamba, Bolivia', December 2005, http://www.bechtel.com/files/perspective -aguas-del-tunari-water-concession/, accessed 10 April 2018; see also Paul Harris, 'Bechtel, Bolivia Resolve Dispute / Company Drops Demand over Water Contract Cancelling', San Francisco Chronicle, 19 January 2006, http://www.sfgate.com/cgi-bin/article.cgi?file=/ c/a/2006/o1/19/MNGM8GPJAKı.DTL, accessed 10 April 2018.

19 Azurix Corp. v. Argentina, ICSID Case No. ARB/o1/12, Award, 14 July 2006.

$20 \quad$ Ibid., para. 144.
} 
condition. ${ }^{21}$ It prompted consumers not to honor their water bills and at the same time prevented ABA from increasing its rates. By the end of 2001 and only two years after the concession had been awarded, Azurix attempted to terminate the agreement, which was at first rejected by the province. In February 2002, after ABA filed for bankruptcy, the province itself terminated the concession, citing an alleged failure by ABA to provide services owed under the concession.

In the context of ICSID proceedings initiated by Azurix, the investor argued that Argentina's measures constituted an indirect expropriation, as well as violations of the fair and equitable treatment, non-discrimination and full protection and security standards. Argentina advanced the argument that there was a conflict between its obligations under investment and human rights law, namely consumers' rights, in which case human rights would necessarily prevail:

The Respondent also raises the issue of a conflict between the BIT and human rights treaties that protect consumers' rights. According to Argentina's expert, a conflict between a BIT and human rights treaties must be resolved in favor of human rights because the consumers' public interest must prevail over the private interest of service provider. On this point, the Claimant argues that the user's rights were duly protected by the provisions made in the Concession Agreement and the Province fails to prove how said rights were affected by the termination. ${ }^{22}$

The Tribunal stated that a conflict between human rights and investment protection norms had not been sufficiently presented, thus preventing any assessment of incompatibility between human rights obligations and the standards of the applicable Bıт:

The Respondent has also raised the issue of the compatibility of the BIT with human rights treaties. The matter has not been fully argued and the Tribunal fails to understand the incompatibility in the specifics of the instant case. The services to consumers continued to be provided without

\footnotetext{
21 The Claimant pointed to 'the analyses of the provincial Central Laboratory of the Ministry of Health which had determined that, "although the Bahía Blanca network water is not drinkable from a physical/chemical standpoint, no microbial contamination that could cause infectious diseases was detected"'; ibid., para. 124.

22 Ibid., para. 254.
} 
interruption by $\mathrm{ABA}$ during five months after the termination notice and through the new provincial utility after the transfer of service. ${ }^{23}$

The Tribunal found the actions of the province were arbitrary and constituted violations of the fair and equitable treatment, as well as the full protection and security standard. ${ }^{24}$

What is particularly interesting about the arguments presented in this case is that Argentina explicitly invoked human rights as a defense, claiming the existence of a hierarchy between human rights provisions and investment protection standards. How Argentina's expert developed this argument is unknown, since neither the legal briefs nor the expert opinions are publicly available. For the reasons illustrated above, the Tribunal did not discuss the concept of such a hierarchy of norms in international law, holding that the matter had not been elaborated upon to a degree permitting the establishment of a conflict of norms. ${ }^{25}$

A different set of circumstances in the same province prompted yet another set of disputes concerning water and sewage supply before an ICSID tribunal. In the Suez cases, ${ }^{26}$ several foreign investors, including the claimants, formed and funded an Argentine company for the purpose of operating a 30-year concession contract in the city of Buenos Aires and 17 other districts of the province. Claimants demanded compensation for an alleged impact upon their business caused by the general economic emergency measures adopted by the Argentine government during the 2002 economic crisis. The investors claimed that Argentinean conduct, such as the freezing of consumer water prices, had violated the FET standard.

In amicus curiae submissions, ${ }^{27}$ civil society organizations requested that the Tribunal should take international and domestic fundamental rights and

\footnotetext{
23 Ibid., para. 261.

24 Ibid., paras. 377, 393, 408.

25 Ibid., para. 261 , see above p. 23.

26 Suez, Sociedad General de Aguas de Barcelona S.A., and InterAgua Servicios Integrales del Agua S.A. v. Argentina, ICSID Case No. ARB/03/17, Decision on Liability, 30 July 2010; $A W G$ Group Ltd. v. Argentine Republic, UnCitral, Decision on Liability, 30 July 2010; Suez, Sociedad General de Aguas de Barcelona S.A. and Vivendi Universal S.A v. Argentine Republic, ICSID Case No. ARB/03/19, Decision on Liability, 30 July 2010.

27 Suez, Sociedad General de Aguas de Barcelona, S.A. and Vivendi Universal, S.A. v. Argentine Republic, ICsID Case No. ARB/o3/19, Order in Response to a Petition for Transparency and Participation as Amicus Curiae, 19 May 2005, para. 23 (formerly Aguas Argentinas, S.A, Suez, Sociedad General de Aguas de Barcelona, S.A. and Vivendi Universal, S.A. v. Argentine Republic).
} 
standards relating to public health, access to essential services, adequate standards of living, housing and consumer rights into consideration. The amici in Suez suggested that ' $[\mathrm{h}]$ uman rights law could displace investment law in two situations examined in this section, namely a situation of conflict of norms and a situation of necessity'.28

Argentina argued that it had taken actions affecting investments out of the necessity of dealing with the financial crisis in order to safeguard essential interests of the State. ${ }^{29}$ The Tribunal mentioned that Argentina had in this context also submitted arguments suggesting its human rights obligations would trump obligations emanating from the applicable BITs and rejected the submission. It held that Argentina was instead compelled to respect both sets of obligations at the same time. Emphasizing that ensuring the human right to water of a population and the fair and equitable treatment of investors were not mutually exclusive, and could well have been achieved by Argentina simultaneously, the Tribunal noted:

Argentina has suggested that its human rights obligations to assure its population the right to water somehow trumps its obligations under the BITs and the existence of the human right to water also implicitly gives Argentina the authority to take actions in disregard of its BIT obligations. The Tribunal does not find a basis for such a conclusion either in the BITs or international law. Argentina is subject to both international obligations, i.e. human rights and treaty obligations, and must respect both of them. Under the circumstances of this case, Argentina's human rights obligations and its investment treaty obligations are not inconsistent, contradictory, or mutually exclusive. Thus, as was discussed above, Argentina could have respected both types of obligations. ${ }^{30}$

28 Suez, Sociedad General de Aguas de Barcelona, S.A. and Vivendi Universal, S.A. v. Argentine Republic, ICSID Case No. ARB/03/19, Amicus Curiae Submission by Amici: Centro de Estudios Legales y Sociales (CELS), Asociación Civil por la Igualidad y la Justicia (ACIJ), Consumidores Libres Cooperativa Lrda. De Provisión de servicios de Acción Comunitaria, Unión de Usuarios y consumidores, Center for International Environmental Law (CIEL), p. 26, http://www.ciel.org/Publications/SUEZ_Amicus_English_4Apro7.pdf, accessed 10 April 2018.

29 Suez, Sociedad General de Aguas de Barcelona S.A., and InterAgua Servicios Integrales del Agua S.A. v. Argentina, ICsid Case No. ARB/03/17, Award, 30 July 2010, para. 230; AWG Group Ltd. v. Argentine Republic, UnCitral, Decision on Liability, 30 July 2010, para. 250; Suez, Sociedad General de Aguas de Barcelona S.A. and Vivendi Universal S.A v. Argentine Republic, ICsid Case No. ARB/03/19, Decision on Liability, 30 July 2010, para. 250.

30 Suez, Sociedad General de Aguas de Barcelona S.A., and InterAgua Servicios Integrales del Agua S.A. v. Argentina, ICSID Case No. ARB/03/17, Award, 30 July 2010, para. 240; in a 
As a result, the Tribunal concluded that Argentina could not justify its interferences with investor rights by invoking either a hierarchy argument or a state of necessity, but was, indeed, obliged to observe both its human rights and BIT obligations. The Tribunal found Argentina liable for breaching the fair and equitable treatment obligations of the BIT.

The dispute in SAUR $v$. Argentina ${ }^{31}$ also developed in the context of the 2002 financial crisis and, to a certain extent, resembles the Suez cases on the facts. SAUR International had invested in a provincially owned water company that held a concession for drinking water, sanitation and sewage in the Argentinean province of Mendoza. After the financial crisis had arisen and all consumer water prices were frozen by the State, tariff renegotiations culminated in a dispute. The project ran into financial difficulties and, perhaps as a consequence, into problems concerning the quality and quantity of sewage and consumer services, as well as the quality of drinking water.

After initiating arbitration proceedings in 2003, SAUR agreed to a 2006 suspension in an effort to reach an amicable settlement, which was achieved in 2007. Yet, subsequent to the provincial authorities' failure to abide by the terms of the settlement, the investment was placed under 'administrative intervention' in August 2009. Claiming technical and operational failure, the province then terminated and renationalized the concession in 2010. It re-awarded it to a State enterprise, while the investor's local company entered liquidation. Arguing that Mendoza's measures constituted an indirect expropriation, as well as violations of the fair and equitable treatment and full protection and security standards of the France-Argentina BIT, SAUR re-initiated ICSID proceedings. ${ }^{32}$ The Tribunal rejected many of the claims due to the fact that they had already been resolved in the settlement, focusing instead on the treatment the investment had experienced since.

Argentina submitted that it had no choice but to terminate and renationalize the concession to ensure provision of services and protect the public interest in health and the right to water. ${ }^{33}$ It also invoked a state-of-necessity defense, ${ }^{34}$ claiming that the measures adopted were a legitimate exercise of

similar wording: AWG Group Ltd. v. Argentine Republic, Decision on Liability, UNCITRAL, 30 July 2010, para. 262; Suez, Sociedad General de Aguas de Barcelona S.A. and Vivendi Universal S.A v. Argentine Republic, ICSID Case No. ARB/03/19, Decision on Liability, 30 July 2010, para. 262. SAUR v. Argentina, ICSID Case No. ARB/04/4, Decision on Jurisdiction and Liability, 6 June 2012.

32 Ibid., para. 229.

33 Ibid., para. 32.

34 Ibid., paras. 451-454. 
'police powers,',35 and asserted that the province had only made use of its contractual rights to terminate the contract due to breaches committed by the concessionaire.

Before examining arguments on various investment protection standards, the Tribunal dealt with Argentina's human rights defense. It recognized that human rights in general and the human right to water in particular had to be taken into consideration. This was justified by the fact that such rights are contained in the Argentinean constitution and constitute general principles of international law and thus are part of the law applicable to the dispute under Article 8(4) of the BIT:

330. In fact, human rights in general, and the right to water in particular, constitute one of the various sources that the Tribunal will have to take into account in resolving the dispute, since these rights are of great importance within the Argentine legal system as constitutional rights, and, moreover, they form part of the general principles of international law. Access to drinking water constitutes, from the point of view of the State, a basic public service and, from the point of view of the citizen, a fundamental right. ${ }^{36}$

The Tribunal also explicitly pointed out that the legal system had to provide for possibilities of planning, supervision, sanctioning, interventions and even a termination of a concession by the authorities to protect the public interest: 37

For this reason, concerning this matter, the legal order can and must reserve for the Public Authority legitimate functions of planning, supervision, police, sanction, intervention and even termination, in order to protect the general interest.

35 Ibid., paras. 328, 394-395.

36 Ibid., para. 330 (author's translation). The original goes: '330. En réalité, les droits de l'homme en général, et le droit à l'eau en particulier, constituent l'une des diverses sources que le Tribunal devra prendre en compte pour résoudre le différend car ces droits sont élevés au sein du système juridique argentin au rang de droits constitutionnels, et, de plus, ils font partie des principes généraux du droit international. L'accès à l'eau potable constitue, du point de vue de l'État, un service public de première nécessité et, du point de vue du citoyen, un droit fondamental'. (Footnote omitted).

37 Ibid., para. 330 (author's translation). The original goes: 'Pour ce motif, en cette matière, l'ordre juridique peut et doit réserver à l'Autorité publique des fonctions légitimes de planification, de supervision, de police, de sanction, d'intervention et même de résiliation, afin de protéger l'intérêt général'. 
Yet, such obligations under human rights law were deemed compatible with those under investment law. If authorities decided to expropriate an investment or to treat it in a manner that amounted to unfair treatment or to a denial of full protection and security, investors would nevertheless enjoy their right to be compensated for such treatment: ${ }^{38}$

331. But these prerogatives are compatible with the rights of investors to receive the protection offered by the в Iт. The fundamental right to water and the right of the investor to benefit from the protection offered by the BIт operate on different levels: the concessionary company of a basic public service is in a situation of dependency on the public administration, which has special powers to guarantee its enjoyment by virtue of the priority of the fundamental right to water; but the exercise of these powers is not absolute and must be combined with respect for the rights and guarantees granted to the foreign investor under the BIT. If the government decides to expropriate the investment, treat the investor unfairly or inequitably, or deny the promised protection or full security, all this by violating the BIT, the investor will be entitled to be compensated under the terms of the Treaty.

332. Counterbalancing these two principles will be the task that the Tribunal will have to perform in its analysis of the substantive claims presented by Sauri. ${ }^{39}$

Furthermore, the Tribunal denied that there was a sufficient causal link between the declaration of a state of necessity and the measures imposed by the

$38 \quad$ Ibid., paras. $33^{1-32}$.

39 Ibid., paras. 331-332 (author's translation). The original goes: '331. Mais ces prérogatives sont compatibles avec les droits des investisseurs à recevoir la protection offerte par l'APRI. Le droit fondamental à l'eau et le droit de l'investisseur à bénéficier de la protection offerte par l'APRI opèrent sur des plans différents : l'entreprise concessionnaire d'un service public de première nécessité se trouve dans une situation de dépendance face à l'administration publique, qui dispose de pouvoirs spéciaux pour en garantir la jouissance en raison de la souveraineté du droit fondamental à l'eau ; mais l'exercice de ces pouvoirs ne se fait pas de façon absolue et doit, au contraire, être conjugué avec le respect des droits et des garanties octroyés à l'investisseur étranger en vertu de l'APRI. Si les pouvoirs publics décident d'exproprier l'investissement, de traiter l'investisseur injustement ou de façon non équitable ou de lui refuser la protection ou la pleine sécurité promises, tout ceci en violant l'APRI, l'investisseur aura le droit d'être indemnisé dans les termes que le Traité lui accorde.

332. Contrebalancer ces deux principes sera la tâche que le Tribunal devra effectuer lors de son analyse des prétentions substantives présentées par Sauri'. 
provincial authorities that led to the expropriation. ${ }^{40}$ As a result, the Tribunal decided that it did not have to enter into a discussion on the question of which circumstances represented a real conflict between the right of access to water and investment protection norms.

After a general discussion on its approach to Argentina's human rights arguments, the Tribunal made no further references to the right to water in its subsequent analyses of substantive treaty violations. In response to the 'police powers' defense invoked by Argentina, it stated that the measures could not be considered a legitimate use of the province's police powers in view of the gravity and deliberateness of the province's failure to abide by the 2007 settlement. ${ }^{41}$ Therefore, the Tribunal found that an expropriation had occurred. It also held that Argentina had violated the standard of fair and equitable treatment by way of the 'financial strangulation' of the concessionaire in order to justify the termination and renationalization of the concession. This conduct was incompatible with the demands of a public administration that is conscientious, impartial and respectful of the rights of its subjects. ${ }^{42}$

The Tribunal in SAUR was prepared to take human rights considerations into account when assessing the police powers of the government. ${ }^{43}$ But apparently, it was of the opinion that the government could not validly invoke such powers in severe disrespect of measures agreed upon in the settlement with the investor. ${ }^{44}$

$40 \quad$ Ibid., paras. $461,463$.

41 Ibid., para. 405.

$42 \quad$ Ibid., paras. 505-506.

43 In para. 396 the Tribunal stated: 'Le Tribunal coïncide avec la République argentine en ce que l'ordre juridique peut octroyer à l'État et à ses organismes régulateurs des pouvoirs spéciaux de réglementation et de police sur des entreprises participant dans certains secteurs économiques, lorsque le comportement incorrect d'une entreprise privée peut avoir des effets collatéraux nuisibles au bien commun : ainsi, la crise d'une banque ou d'un établissement de valeurs peut provoquer un risque systémique pour l'ensemble du secteur financier, ou les agissements irresponsables d'une entreprise prestataire de services de première nécessité peuvent dégénérer en risques graves pour la santé et le bien-être de la citoyenneté. Dans tous ces cas, il est justifié que l'État se réserve, pour la protection et au bénéfice de la société dans son ensemble, des pouvoirs spéciaux lui permettant d'interférer dans la gestion, voire même dans la propriété, de l'entreprise privée afin de redresser la situation.'

44 In para. 405 the Tribunal stated: 'En résumé : le Tribunal estime que la gravité du non respect du second Protocole l'empêche d'accepter la défense de la République argentine selon lesquelles agissements se sont limités à un usage légitime de ses pouvoirs de police.. 
The Urbaser $v$ Argentina ${ }^{45}$ case also arose in the context of Argentina's 2001-2002 financial crisis. The claimant was a shareholder in a concessionaire providing water and sewage services in the Province of Buenos Aires. Contrary to its obligations under the concession, the investor never invested in the expansion of services to the degree necessary to achieve the broad coverage of the agreed extent. Urbaser argued that a number of measures adopted by the province of Buenos Aires had rendered a profitable operation of its concession impossible. The investor also alleged that renegotiations of the concession agreement had been conducted in a manner that led to its termination, in an effort to return utility concessions to the State. Argentina responded with the argument that the investment had not failed as a consequence of measures to cope with the financial crisis (tariff freezes), but rather as a result of the shareholders' deficient management and failure to fulfil obligations under the agreement. In this sense, this case too concerned issues of affordability as well as physical access to water.

In the context of the issue of water affordability for the population, the Tribunal had to decide upon the legality of the tariff freeze and its consequences. It did not consider that a violation of FET or an expropriation had taken place in this regard. Instead, it took Argentina's human rights obligations into account when interpreting the FET provision of the Argentina-Spain BIT. With a view to the compatibility of human rights with investment law obligations, the Tribunal decided that the State was obliged to fulfil both of them simultaneously. ${ }^{46}$ Deciding that the Province was obliged to guarantee the continuation of a basic water supply, the Tribunal held that this universal basic human right constituted part of the framework of claimant's legitimate expectations. ${ }^{47}$

Given the major impact of the emergency measures on the investment, in isolation, the Tribunal would have deemed them to breach the FET standard. ${ }^{48}$ Noting that the investment had already been struggling, however, it found that the emergency measures did not represent the cause of the failure to meet obligations under the concession. As a result, it decided that the emergency measures per se did not constitute a violation of the FET standard. ${ }^{49}$ In addition, it found that the state of necessity defense was available to Argentina.

45 Urbaser S.A. and Consorcio de Aguas Bilbao Bizkaia, Bilbao Biskaia Ur Partzuergoa v. Argentine Republic, ICSID Case No. ARB/o7/26, Award, 8 December 2016.

46 Ibid., para. 720.

47 Ibid., paras. 623-624.

48 Ibid., para. 680 .

49 Ibid., paras. 680-683. 
The authorities had only breached the FET provision of the BIT by engaging the investor in doomed renegotiations of the concession contract. ${ }^{50}$ But since the concession had no future due to the failure of the claimants to make the necessary investments, the Tribunal did not award damages. ${ }^{51}$

In summary, the Tribunal resolved a perceived conflict between investment law and human rights law obligations. It did so by applying international human rights norms to interpret the legitimate expectations under the FET standard of the BIT.

\section{4}

\section{Physical Access}

The second dimension of the right to water is physical access. Often, lack of connections or a poor water supply system has led States to opt for privatization. This is typically achieved by a contract with an investor that establishes the conditions, such as the number of connections, tariffs and ideally rules ensuring that the poor can also afford water. Unfortunately, not all of these contracts are fulfilled as they should be by the foreign investor and the State has to intervene to ensure access to water for its citizens. The Biwater Gauff52 case is an example of such a situation. Tanzania terminated a water supply concession because the investor did not fulfil its obligations under the concession and endangered access to water for the citizens of Daar es Salaam..$^{53}$ In the Biwater Gauff case, human rights could have served as a justification for the interference with the investor's rights. However, only the amici and neither the respondent nor the Tribunal made any explicit reference to the human right to water.

The government only relied on human rights in a very indirect way. ${ }^{54}$ The award mentions that the government stated that ' $[\mathrm{w}]$ ater and sanitation services are vitally important, and the Republic has more than a right to protect such services in case of a crisis: it has a moral and perhaps even a legal obligation to do so.'55

The defense of the State in this regard was successful, since the Tribunal held that terminating the investment agreement because of the investor's

\footnotetext{
5o Ibid., paras. $843-847$.

$5^{1} \quad$ Ibid., paras. 846-847.

$5^{2}$ Biwater Gauff (Tanzania) Ltd. v United Republic of Tanzania, ICSID Case No. ARB/05/22, Award, 24 July 2008.

53 Ibid., para. 789 .

54 Ibid., paras. $434,814$.

55 Ibid., para. 434.
} 
poor performance was neither a breach of contract nor the FET standard. The Tribunal stated that it took the amicus curiae brief into consideration. ${ }^{56}$ But neither the term human rights nor any human rights-related assessment can be found in the Tribunal's own reasoning. The case was decided purely on matters of investment law. The Tribunal did not consider the termination of the contract to constitute a violation of the BIT. ${ }^{57}$

A linkage with the human right to water might have been useful to exemplify situations where an interference with investors' rights is justified to uphold human rights obligations. Given the fact that the Tribunal ultimately decided the case in a way that respects the human rights obligations of the State, one cannot reproach it with this omission, particularly as the State did not rely on them in an explicit form.

The second case of interest in this context is the already mentioned $U r$ baser $v$ Argentina case. ${ }^{58}$ In the context of physical access to water, Argentina brought a counterclaim. It argued that the concessionaire's failure to provide the necessary investment for the expansion of the network violated the investor's commitments and its obligations under international law based on the human right to water. ${ }^{59}$ The Tribunal accepted jurisdiction for the counterclaim and noted obiter that investors can violate the human right to water by destroying access to water. Therefore, they themselves are subject to an obligation to abstain from such acts. ${ }^{60}$ The Tribunal found, however, that the question of destruction of access did not arise. ${ }^{61}$

The Tribunal based this finding of an 'obligation to abstain' on Article 30 of the Universal Declaration of Human Rights, ${ }^{62}$ Article 5 of the Covenant on Economic, Social and Cultural Rights ${ }^{63}$ as well as on Principle 8 of the

$56 \quad$ Ibid., para. 392.

57 Ibid., paras. $488,791$.

$5^{8}$ See above p. 13. Urbaser S.A. and Consorcio de Aguas Bilbao Bizkaia, Bilbao Biskaia Ur Partzuergoa v. Argentine Republic, ICSID Case No. ARB/o7/26, Award, 8 December 2016.

59 Ibid., para. 36.

$60 \quad$ Ibid., para. 1210.

$61 \quad$ Ibid., para. 1210.

62 Article 30 of the Universal Declaration on Human Rights, A/REs/3/217, 10 December 1948: 'Nothing in this Declaration may be interpreted as implying for any State, group or person any right to engage in any activity or to perform any act aimed at the destruction of any of the rights and freedoms set forth herein'.

63 Article 5 of the 1966 International Covenant on Economic, Social and Cultural Rights (adopted 16 December 1966, entered into force 3 January 1976) UNTS 993; 3; '1. Nothing in the present Covenant may be interpreted as implying for any State, group or person any right to engage in any activity or to perform any act aimed at the destruction of any of 
International Labor Office's Tripartite Declaration of Principles concerning Multilateral Enterprises and Social Policy ${ }^{64}$ (1977 as amended 2006). ${ }^{65}$

Article 30 of the Universal Declaration of Human Rights as well as Article 5 of the Covenant on Economic, Social and Cultural Rights prevent reliance on rights contained in these documents to destroy other rights contained in the respective instrument. ${ }^{66}$ However, they do not forestall reliance on another treaty. Specifically, they do not prevent an investor from relying on а віт. The International Labor Office's Tripartite Declaration is a soft law document that does not create binding obligations for corporations under international law. Therefore, it is doubtful whether these provisions can be used to establish a human rights obligation for investors to abstain from interfering with a population's right to water.

With regard to the issue at stake, namely a potential obligation under international law to create water connections and expand the network, the Tribunal found that under current international law there was no positive obligation for investors to provide access to water based on international human rights law. The acceptance of the Bid and the Concession Contract could not create such an obligation under international law. ${ }^{67}$ Therefore, the counterclaim failed on the merits.

the rights or freedoms recognized herein, or at their limitation to a greater extent than is provided for in the present Covenant. 2. No restriction upon or derogation from any of the fundamental human rights recognized or existing in any country in virtue of law, conventions, regulations or custom shall be admitted on the pretext that the present Covenant does not recognize such rights or that it recognizes them to a lesser extent'.

64 ILO, 'Tripartite Declaration of Principles concerning Multilateral Enterprises and Social Policy, adopted by the Governing Body of the International Labour Office at its $204^{\text {th }}$ Session (Geneva, November 1977) and amended at its $279^{\text {th }}$ (November 2000), 295 ${ }^{\text {th }}$ (March 2006) and $329^{\text {th }}$ (March 2017) Sessions', http://www.ilo.org/wcmsp5/groups/public/---ed_ emp/---emp_ent/---multi/documents/publication/wcms_094386.pdf, accessed 10 April 2018.

65 Urbaser S.A. and Consorcio de Aguas Bilbao Bizkaia, Bilbao Biskaia Ur Partzuergoa v. Argentine Republic, ICSID Case No. ARB/o7/26, Award, 8 December 2016, paras. 1196-1199.

66 Edward Guntrip, 'Urbaser v Argentina: The Origins of a Host State Human Rights Counterclaim in ICSID Arbitration?', EJIL: Talk!, 10 February 2017, https://www.ejiltalk.org/ urbaser-v-argentina-the-origins-of-a-host-state-human-rights-counterclaim-in-icsid-ar bitration/, accessed 10 April 2018; on Article 5(1) CESCR see: Ben Saul, David H. Kinley and Jacqueline Mowbray, The International Covenant on Economic, Social and Cultural Rights, (Oxford: Oxford University Press, 2014), pp. 263 et seq.

67 Urbaser S.A. and Consorcio de Aguas Bilbao Bizkaia, Bilbao Biskaia Ur Partzuergoa v. Argentine Republic, ICSID Case No. ARB/07/26, Award, 8 December 2016, para. 1212. 
The third dimension of the right to water is its quality and protection from pollution. The quality of water may lead to investment disputes in various settings. One relates to water service providers where problems with the quality of drinking water arise. Respondents in such circumstances have repeatedly invoked the lack of quality as justification for a renationalization of the concession. The relevant cases, such as Azurix and Saur, also had an affordability component and have, therefore, already been discussed above. ${ }^{68}$

Another setting where pollution was at stake is where the undesired side effects of operations have allegedly led to a danger to the quality of drinking water or endangered maritime environments or rivers. In particular, mining operations, as well as power plants, or industrial products that contaminate water can cause such effects. ${ }^{69}$ Several cases have concerned the potential pollution of ground water and rivers, as well as maritime environments.

In the cases that have already been decided, Methanex $v$. United States, ${ }^{70}$ Clayton/Bilcon v. Canada ${ }^{71}$ and Pacific Rim v. El Salvador, ${ }^{72}$ authorities had acted to protect the public interest in one form or another - in Methanex and Pacific Rim, drinking water and in the Clayton/Bilcon a maritime environment.

In Pacific Rim v. El Salvador, ${ }^{73}$ the investor sued El Salvador because of its refusal to grant a gold-mining permit. El Salvador argued that it had denied the permit because of concerns about the potential negative social and

68 a) In the Section on Access - Affordability; see, for instance, Azurix Corp. v. Argentina, ICSID Case No. ARB/o1/12, Award, 14 July 2006, paras. 128-131; SAUR v. Argentina, ICSID Case No. ARB/04/4, Award, 6 June 2012, paras. 32, 178(iv), 394.

69 Vattenfall I (Vattenfall AB, Vattenfall Europe AG, Vattenfall Europe Generation AG \& Co. KG v. Federal Republic of Germany), ICSID Case No. ARB/og/6, could potentially fall into this category of cases since a water use permit and the quality of water used to cool the power plant was at stake. The dispute concerned the construction of a coal-fired power plant in Hamburg by the Swedish investor Vattenfall. It was settled and most of the facts are not publicly available. The Tribunal embodied the terms of the agreement between the parties in an award. The award (11 March 2011) does not contain the details of the settlement but states that a modified water use permit had been issued. Since no more details are publicly available no conclusions can be drawn from this case.

$70 \quad$ MethanexCorp. v. USA, NAFTA, Final Award, 3 August 2005.

71 Clayton/Bilcon v. Canada, PCA Case No. 2009-04, Award on Jurisdiction and Liability, 17 March 2015 .

72 Pac Rim v. El Salvador, ICSID Case No. ARB/og/12, Decision on the Respondent's Preliminary Objections, 2 August 2010.

Ibid., para. 11 . 
environmental impacts of gold mining in El Salvador, including water pollution and health risks. ${ }^{74}$ The Tribunal did not reach the question whether these concerns would justify the denial of a permit but decided the case by negating Pac Rim's entitlement to an exploitation concession under El Salvador's mining law. ${ }^{75}$ Therefore, no results for our question can be drawn from this case.

In the two other cases, Methanex and Clayton, legitimate expectations played a key role in the decisions of investment tribunals. Both cases demonstrate that bona fide regulation to ensure that water resources are protected against pollution will not lead to a violation of investment protection standards, except where specific promises to the contrary have been made. This is true for regulation ensuring the non-pollution dimension of the human right to water, as well as for regulation in the realm of environmental protection of water.

With regard to the clean drinking water dimension, the Methanex ${ }^{76}$ tribunal has made this very clear. The case concerned a Canadian producer and distributor of methanol, the main ingredient in the gasoline additive methyl tertiary-butyl ether (МтвЕ), with operations in the United States and other countries. The dispute arose out of a Californian ban on the use of MTBE in the state. While мтве has a positive effect on air quality, the Californian legislator considered мтве to pose environmental and public health risks arising from its possible seepage into groundwater, including into sources of drinking water, and that those risks outweighed any clean air benefits derived from its use in gasoline. ${ }^{77}$

The investor argued that the ban was tantamount to an expropriation of the company's investment and thus a violation of Article 1110 NAFTA; that it was enacted in breach of the national treatment obligation in Article 1102 of NAFTA; and that it was also in breach of the international minimum standard of treatment in Article 1105 of NAFTA. ${ }^{78}$

The Tribunal found that no violation of the national treatment standard had occurred ${ }^{79}$ and that Article 1105 NAFTA had equally not been violated by

74 Pac Rim v. El Salvador, ICSID Case No. ARB/og/12, The Republic of El Salvador's CounterMemorial on the Merits, 10 January 2014, paras. 58-63, 208.

75 Pac Rim v. El Salvador, ICSID Case No. ARB/og/12, Final Award, 14 October 2016, para. 10.4.

76 MethanexCorp. v. USA, NAFTA, Final Award, 3 August 2005.

77 мтве Public Health and Environment Protection Act of 1997, California Senate Bill No. 521, Chapter 816, 9 October 1997, http://www.leginfo.ca.gov/pub/97-98/bill/sen/sb_05010550/sb_521_bill_19971009_chaptered.html, accessed 10 April 2018.

78 MethanexCorp. v. USA, NAFTA, Final Award, 3 August 2005, Part IV - Chapter A, para. 1.

79 Ibid., Part IV, Chapter B, para. 38. 
the Mтве ban. ${ }^{80}$ With regard to its expropriation claim, Methanex relied in large part on the approach of the Metalclad $v$. Mexico Tribunal, which applied the sole effects doctrine ${ }^{81}$ and highlighted the economic impact of a regulatory measure as the key factor for analysis under Article 1110 NAFTA. ${ }^{82}$ The Methanex Tribunal noted that neither a direct nor a creeping expropriation had taken place and that, if at all, the measures taken were tantamount to expropriation. However, it found that, in accordance with general international law, a non-discriminatory measure in the public interest taken in accordance with due process requirements that targets, amongst others, foreign investors, is not an expropriation. Therefore, no compensation will be required unless the government made specific commitments:

[A]s a matter of general international law, a non-discriminatory regulation for a public purpose, which is enacted in accordance with due process and, which affects, inter alios, a foreign investor or investment is not deemed expropriatory and compensable unless specific commitments had been given by the regulating government to the then putative foreign investor contemplating investment that the government would refrain from such regulation. ${ }^{83}$

The Methanex Tribunal confirmed this reasoning a few paragraphs later where it stated that '[f]rom the standpoint of international law, the California ban was a lawful regulation and not an expropriation' ${ }^{84}$ The criteria 'public interest', 'non-discriminatory' and in line with 'due process' requirements were no longer used to establish whether the expropriation was lawful. Rather, they were used to determine whether an expropriation had occurred at all. The repercussions on the investor did not play a decisive role. This was a major departure from the classical method whereby these criteria were used only to decide whether a given expropriation was lawful.

In its reasoning on expropriation the arbitral tribunal in Methanex pointed out that the investor knew that it had invested in an economic branch that

8o Ibid., Part IV, Chapter C, para. 27 .

81 See e.g. Ursula Kriebaum, 'Expropriation' in Mark Bungenberg, Jörn Griebel, Stephan Hobe and August Reinisch (eds.), International Investment Law (Baden-Baden: Nomos, 2015), pp. 959-1030, paras. 132-148.

$82 \quad$ Metalclad Corp v. Mexico, ICSID Case No. ARB(Af)/97/1, Award, 30 August 2000, para. 103.

83 MethanexCorp. v. USA, NAFTA, Final Award, 3 August 2005, Part IV - Chapter D, para. 7.

84 Ibid., Part IV - Chapter D, para. 15. 
was characterized by changing regulations and restrictions and that it had not obtained any special promises:

Methanex entered a political economy in which it was widely known, if not notorious, that governmental environmental and health protection institutions at the federal and state level, operating under the vigilant eyes of the media, interested corporations, non-governmental organizations and a politically active electorate, continuously monitored the use and impact of chemical compounds and commonly prohibited or restricted the use of some of those compounds for environmental and/ or health reasons. Indeed, the very market for мтвE in the United States was the result of precisely this regulatory process. Methanex appreciated that the process of regulation in the United States involved wide participation of industry groups, non-governmental organizations, academics and other individuals, many of these actors deploying lobbyists....

Methanex entered the United States market aware of and actively participating in this process. It did not enter the United States market because of special representations made to it. ${ }^{85}$

Therefore, the United States prevailed with its defense that it had legislated to protect its ground and drinking water resources and the Tribunal found neither an expropriation nor a violation of FET.

The Tribunal in Clayton also explicitly stressed the regulatory space of the legislator and hinted at a need for sensitivity with respect to legislation in the field of the environment to prevent regulatory chill. ${ }^{86}$ However, both Tribunals also confirmed that host State representations, assurances or promises aimed at persuading a specific investor to make a particular investment may give rise to legitimate expectations that can result in a breach of the FET standard or constitute an indirect expropriation if the State does not live up to its promises and the other requirements for a violation of these standards are met. In the Clayton case it was arbitrary administrative conduct and broken explicit promises of the administration that led to findings of violations of investment protection standards. Therefore, encouragements to invest and promises made in this context should not be taken lightly by States, especially when human rights or environmental law concerns are at stake.

85 Methanex Corp. v. USA, NAFTA, Final Award, 3 August 2005, Part IV - Chapter D, paras. 9, 10.

86 Clayton/Bilcon v. Canada, PCA Case No. 2009-04, Award on Jurisdiction and Liability, 17 March 2015, paras. 737-738. 
Investment tribunals have, in principle, recognized the existence of a human right to water and expressed their willingness to take it into consideration. None of the tribunals mentioned herein questioned the existence of such a right. The Tribunal in SAUR explicitly stated that human rights constitute applicable law and demonstrated its willingness to consider human rights obligations under the heading of legitimate police powers of a State.

Investment tribunals have all found that investment law and human rights law obligations could be met at the same time. They did not accept a hierarchy between the right to water and investor rights. Furthermore, they did not frame the potential tensions between the right to water and investor rights as a normative conflict. Rather, tribunals have opted for a systemic integration of human rights obligations into investment law and found that both obligations apply in parallel and can be met at the same time.

The concept of legitimate expectations plays a key role in the simultaneous compliance with investment and human rights obligations by host States. In Urbaser, the Tribunal indicated how the concept can be employed to incorporate interferences with investor rights that are designed to ensure a minimum essential level of water for the population, into the framework of investment standards. Similarly, the Tribunal in Methanex relied on this concept to deny the existence of an indirect expropriation. As a result, unless a State has made specific promises to the contrary, investors will not be able to claim a legitimate expectation that a State will not take measures to ensure that it complies with its human rights obligations under the right to water, be it in the context of affordability, physical access or protection against pollution.

Based on the abovementioned case law, it appears fair to conclude that legislative amendments designated to protect against the pollution of water resources will not lead to finding violations of international investment standards. The same holds true for terminations of water concessions as a consequence of inadequate performance of an investment contract on the part of the investor. On the other hand, arbitrary administrative procedures that run counter to legitimate expectations created by the State may well breach investment protection standards. 